\title{
Interactive comment on "Recent rift formation and impact on the structural integrity of the Brunt Ice Shelf, East Antarctica” by Jan De Rydt et al.
}

\section{Anonymous Referee \#1}

Received and published: 17 October 2017

The comment was uploaded in the form of a supplement: https://www.the-cryosphere-discuss.net/tc-2017-190/tc-2017-190-RC1supplement.pdf

Interactive comment on The Cryosphere Discuss., https://doi.org/10.5194/tc-2017-190, 2017. 